\title{
Anatomy of the Skull of Saanen Goat. An anesthesiology and Stereology Approach
}

\author{
Anatomía del Cráneo de la Cabra Saanen. Un Enfoque desde la Anestesiología y la Estereología
}

\author{
Xiangyang Wang'; Anjun Liu'; Jing Zhao²; Fathy M. Elshaer ${ }^{3,4}$ \& Diaa Massoud ${ }^{3,5}$
}

WANG, X.; LIU, A.; ZHAO, J.; ELSHAER, F. M. \& MASSOUD, D. Anatomy of the skull of Saanen goat. An anesthesiology and stereology approach. Int. J. Morphol., 39(2):423-429, 2021.

SUMMARY: The Saanen goat is known as the greatest milk producer among small ruminat breeds. However, its morphometric features still remain unclear. Therefore, the present work aimed to investigate the functional anatomy of the upper and lower jaws as well as the volumetric properties of the male and female Saanen goat for clinical applications. The heads of 20 adult animals (10 males and 10 females) were included. Totally, 22 morphometric parameters were measured on three dimensional computed tomographic images using RadiAnt DICOM Viewer software and some parameters were measured on hot macerated sample. The mean volume of paranasal sinuses as well as conchal sinuses were estimated using stereological method. Based on the results, the differences between males and females were not significant ( $p>0.05)$ in all desired parameters. The frontal and lacrimal sinuses were the largest and smallest paranasal sinus in both sexes. Also, the dorsal and middle conchal sinuses were the largest and smallest ones, respectively. The common nasal meatus was the smallest and ventral meatus was the largest meatus in the nasal cavity.In conclusion, these findings provide a basic data that would be useful in blocking terminal branches of the cranial nerves in this breed for surgical purpose or teeth injuries treatment.

KEY WORDS: Applied anatomy; CT scan; Morphometry; Ruminant; Stereology.

\section{INTRODUCTION}

The superficial landmarks of anatomical features in the skull region can be attributed to the genetic and environmental factors which would be helpful in interpreting extensive variety in the phenotyping between and within breeds or species. Accurate knowledge of the anatomical structure of the skull can be an effective aid in ontogenic studies as well as the determination of sexual polymorphisms. (Olopade \& Onwuka, 2008).

Previously, skull morphometry and its applied clinical anatomy have been performed on different wild species (Onar et al., 2005; Sarma, 2006), domestic animals (Onar, 1999; Baranowski, 2010) and farm animals (Jakubowski et al., 2008; Parés I Casanova et al., 2010). In addition, different breeds of goat including West African Dwarf goat (Olopade \& Onwuka, 2005), Nigerian Red Sokoto goat, (Olopade \& Onwuka, 2008), Iranian native goat (Monfared et al., 2013), Black Bengal goat (Uddin et al., 2009), and Markhoz goat (Goodarzi \& Hoseini, 2014) have been previously subjected to skull morphometric analysis.
Computed tomography (CT) is a reliable, and noninvasive procedure for evaluating different pathological lesions or diseases in the head region as compared to the traditional radiography (Frazho et al., 2008). Although, this modality has been used widely for describing the normal structure of head and other body regions in animals world (Morrow et al., 2000; Frazho et al.), however, the combination of imaging techniques and stereological procedures has received little attention in veterinary practice.

The Saanen goat which originates Saanen Valley of Switzerland, is known as the greatest milk producer among small ruminat breeds (Kurtul \& Atalgin. 2008). Despite the great values of this breed, there is a little data about the morphometric and anatomical features of the skull in the Saanen goat. Therefore, this work was designed to present comprehensive morphometric data of the skull in this breed with special reference to its regional anesthesia as well as to present the normal values of the paranasal and conchal sinuses volume. The obtained results will compare to the other relevant

\footnotetext{
${ }^{1}$ Department of Rehabilitation Medicine, the 960th Hospital of the Joint Service of the Chinese People's Liberation Army, Jinan,Shandong, 250031, China.

${ }^{2}$ Department of Anesthesiology, the 960th Hospital of the Joint Service of the Chinese People's Liberation Army, Jinan, Shandong, 250031, China.

${ }^{3}$ Department of Biology, College of Science, Jouf University, P.O. Box 2014, Sakaka, Al-Jouf, Saudi Arabia.

${ }^{4}$ Department of Zoology, Faculty of Science, Al-Azhar University, Nasr City, Cairo, Egypt.

${ }^{5}$ Department of Zoology, Faculty of Science, Fayoum University, Fayoum, Egypt.
} 
results. This information would be useful for veterinarians who are involved in small ruminant clinical practices.

\section{MATERIAL AND METHOD}

The heads of 20 adult Saanen goats (10 males and 10 females) were used in this work. The heads were separated from the goats that died because of diseases unrelated to the head or neck and transferred to the dissection room, Zoology Department, Faculty of Science, Fayoum University, Fayoum, Egypt. The present research was performed in accordance with the recommendations of the National Institutes of Health's Guide for the Care and Use of Laboratory Animals. The research protocol was approved by the Scientific Ethics Committee of Fayoum University. Ten heads were used for computed tomographic (CT) imaging and another ten samples were processed by hot maceration technique to measure some parameters that could not be investigated with CT images.

Computed tomographic imaging. The head samples were used for CT scan imaging with a helical scanner (SiemensSomatom ${ }^{\circledR}$ - 2 detectors, Germany/ Kvp: 105 VmAs: 130 and slice thickness: $1.5 \mathrm{~mm})$. All CT scan images were investigated using an image analysis workstation (Clear Canvas by Synaptive Medical, Toronto, Canada) and Afterward, 3D reconstruction was done using the using RadiAnt DICOM Viewer software.

Volume estimation. In the present work a combination of un-biased and designed-based stereology and CT scan were

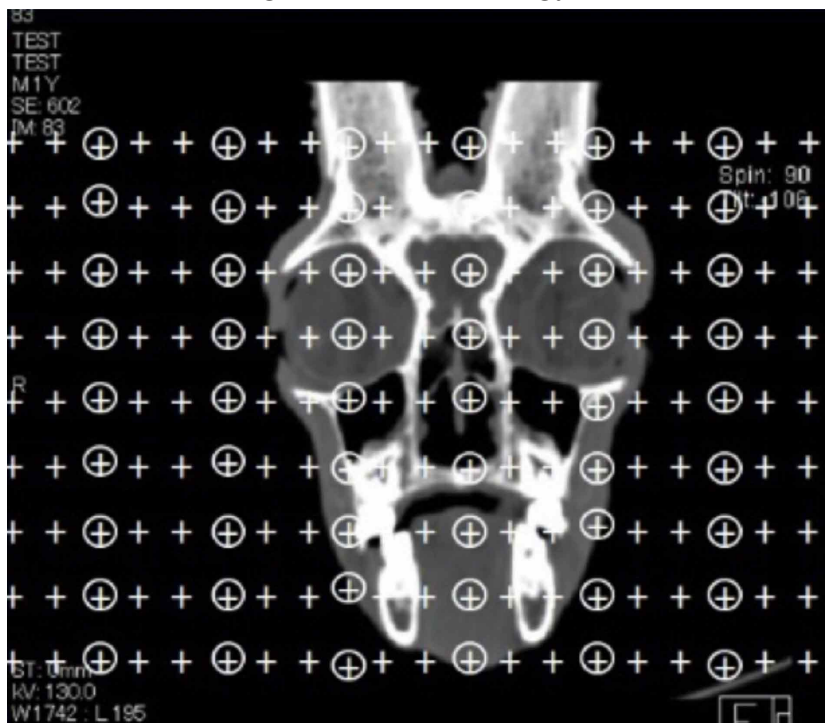

Fig. 1.Transverse CT scan image of the Saanen goat skull superimposed with a compound point grid for estimating the volume density of desired cavities using Cavalieri principle. used for estimating the absolute volume of the paranasal sinuses. For this purpose, Cavalieri principle was performed on the obtained CT scan images. On average, 121 images were selected from each animal. A point probe constituted of 220points (+) was superimposed on each CT scan image and the fractional volume of the cavities was estimated using the following formula:

$$
\mathrm{V}_{\mathrm{v}(\text { structure/reference) }}=\sum \mathrm{P}_{\text {structure }} / \sum_{\text {Preference }}
$$

In this formula, $\sum \mathrm{P}_{\text {structure }}$ isthe sum of the points hit the desired cavities and $\sum \mathrm{P}_{\text {reference }}$ is thesum of the points hit the total section area (Fig. 1). The fractional volume was multiplied by the total volume of the skull. Therefore, the following formula was applied to determine the reference volume:

$$
\left.\mathrm{V}^{\text {total }}=\sum \mathrm{P} \times[\mathrm{SU}] \times \mathrm{d} / \mathrm{SL}\right]^{2} \times \mathrm{t}
$$

In this formula. $\sum \mathrm{P}$ is the sum of the points hit the whole sections, $\mathrm{SU}$ is the scale unit, $\mathrm{d}$ is the distance between two points, SL is the scale length, and $\mathrm{t}$ is the section interval.

The coefficient of error (CE) of the Cavalieri estimate of volume was predicted using the following formula (Gocmen-Mas et al., 2009):

$$
C E(V)=\frac{1}{x P}\left(\frac{1}{12}\{3 a+c-4 b\}\right)^{\frac{2}{2}}
$$

$$
\text { Where, } a=\sum_{i=1}^{m} P i . P i, b=\sum_{i=1}^{m} P i . P i+1 \text { and } c=\sum_{i=1}^{m} P i . P i+2
$$
I

Morphometric measurements. The 3D images underwent morphometric measurements in RadiAnt DICOM

Viewer software and totally twenty- two parameters in upper and lower skull were described as below (Figs. 2 to 4):

1. Skull length (SL); was measured as a distance between the rostral point of the incisive bone to the external occipital protuberance of the occipital bone.

2.Skull height $(\mathrm{SH})$; was measured as a distance from the summit of the frontal bone to the tip of the paracondylar process.

3. Skull width (SW); was measured as a distancethe distance between the lateral margins of the eyes.

4. Cranial length (CL); was the distance between the nuchal crest and the caudal rims of the eyes.

5. Cranial width $(\mathrm{CW})$; was the distance between the most lateral points of the cranial cavity at the level of the external acoustic meatus.

6. Facial length (FL); was the distance between the nasofrontal suture and the most rostral point of the incisive bone.

7. Facial width $(\mathrm{FW})$; was the distance between the rostral rims of the eyes. 
8. Mandibular height $(\mathrm{MH})$; was a perpendicular line which connected the tip of the coronoid process to the ventral margin of the mandible.

9. Mandibular length (ML) was measured as a distance from the caudal margin of the ramus to the incisive teeth.

10. Bar length (BL); was the distance between the most lateral incisive tooth and first premolar teeth.

11. FI the distance between the facial tuberosity and infraorbital foramen.

12. MFIDwas measured as a distancefrom the mental foramen to the most lateral incisive tooth.

13. MFPD was measured as a distancefrom the mental foramen to the cranial margin of the first premolar tooth.

14. MFVD was measured as a distance from the mental foramen to the ventral margin of the mandibular body.

15. MFC was measured as a distance from the mental foramen to the caudal margin of the mandibular ramus.

16. M1; was the distance between the ventral margin of the mandibular foramen and ventral margin of the mandible.

17. M2; was the distance between the mandibular foramen and caudal margin of the ramus.

18. M3; was the shortest distance between the mandibular foramen and caudal angle of the mandible.

19. Skull index; Skull width / skull length $\times 100$

20. Facial index; Facial width / facial length $\times 100$

21. Cranial index; Cranial width / cranial length $\times 100$

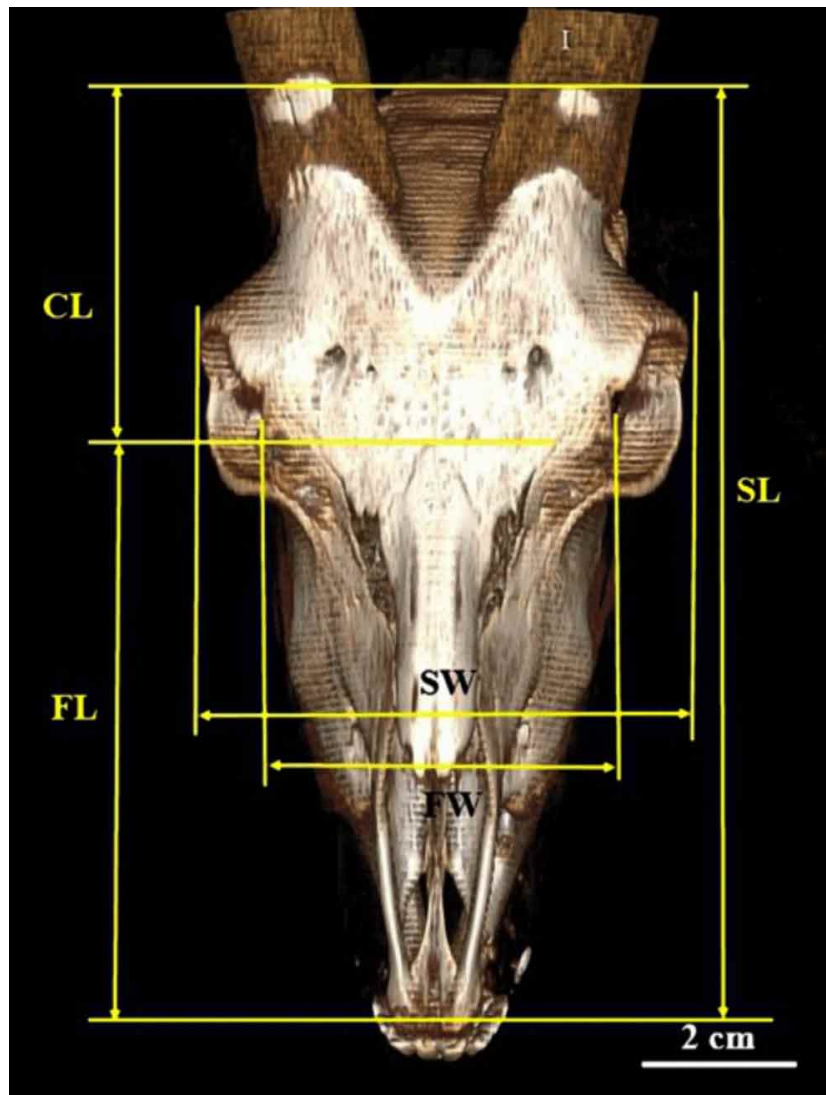

Fig. 2. 3D reconstruction of the Saanen goat skull is shown on dorsal view. SL: Skull length, FL: facial length, CL: cranial length, SW: skull width, FW: facial width.

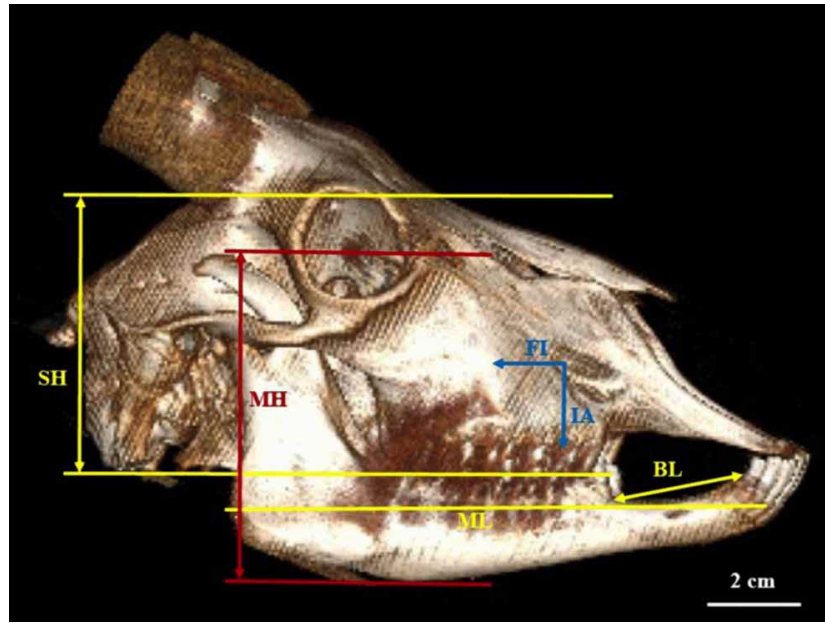

Fig. 3. 3D reconstruction of the Saanen goat skulls shown on lateralview. SH: skull height, ML: mandibular length, MH: mandibular height, BL: bar length, FI: facial tuberosity to infraorbital foramen, IA: Infraorbital foramen to alvelolar tooth.
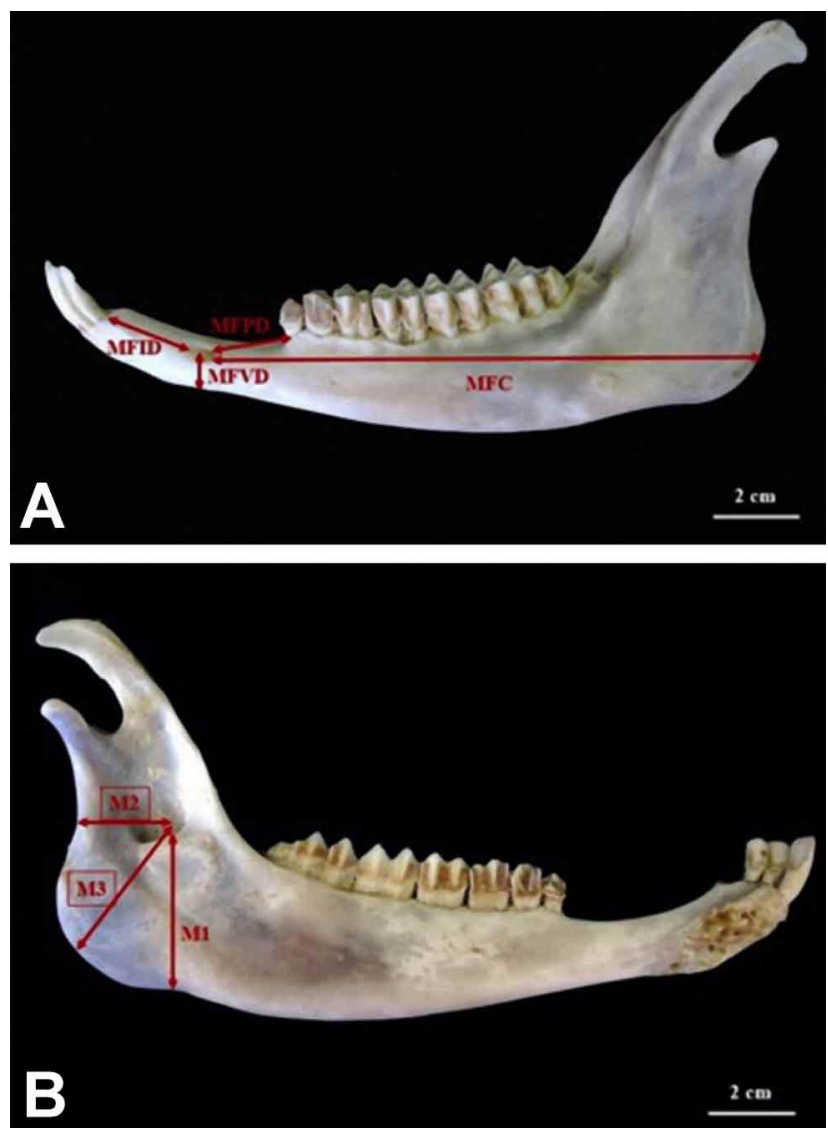

Fig. 4. (a) Lateral and (b) medial views of the mandible of the Saanen goat.MFID: mental foramen to the most lateral incisive tooth, MFPD: mental foramen to the first premolar tooth, MFVD: mental foramen to the ventral margin of the mandibular body, MFC: mental foramen to the caudal margin of the mandibular ramus. M1: mandibular foramen to the ventral margin of the mandible, M2: mandibular foramen to the caudal margin of the mandible, M3: mandibular foramen to the most caudal angle of the mandible. 
Statistical analysis. The obtained data are presented as mean \pm standard deviation (SD). The difference between males and females animals was analyzed using Student t-test in the SPSS software version 20.0 (SPSS, Inc., Chicago, IL) and differences were considered significant at $\mathrm{P}$ value less than 0.05 .

\section{RESULTS}

Stereological fidings. The total volume of the head cavities, and paranasal sinuses are presented in Table I. The frontal sinus was the largest paranasal sinusin Saanen goat with volume $186.16 \pm 0.77 \mathrm{~cm}^{3}$ in males and $174.6 \pm 2.26 \mathrm{~cm}^{3}$ in femals. The dorsal nasal concha contained a sinus with volume $25.15 \pm 1.69 \mathrm{~cm}^{3}$ in male goats and $26.8 \pm 1.77 \mathrm{~cm}^{3}$ in female ones, which was larger than middle and ventral conchal sinuses. Estimation of the volume of nasal meatuses showed that ventral nasal meatus with volume $5.3 \pm 0.29 \mathrm{~cm}^{3}$ in males and $4.82 \pm 0.5 \mathrm{~cm}^{3}$ in females was the largest meatus in the nasal cavity of the Saanen goat.

Table I. Total volume $\left(\mathrm{cm}^{3}\right)$ of paranasal and conchal sinuses in the Saanen goat $(n=20)$ are expressed as Mea \pm SD.

\begin{tabular}{lccc}
\hline & Male & Female & P-value \\
\hline Ms & $186.61 \pm 0.65$ & $175.94 \pm 0.28$ & 0.22 \\
Fs & $221.2 \pm 9.27$ & $227.73 \pm 6.75$ & 0.17 \\
Ls & $35.51 \pm 4.77$ & $35.22 \pm 3.85$ & 0.35 \\
Dcs & $26.55 \pm 2.84$ & $27.15 \pm 2.14$ & 0.19 \\
Mcs & $13.57 \pm 1.22$ & $13.35 \pm 1.15$ & 0.15 \\
Vcs & $22.84 \pm 1.12$ & $21.19 \pm 1.44$ & 0.25 \\
Dm & $3.26 \pm 0.95$ & $318.2 \pm 0.74$ & 0.18 \\
Mm & $2.35 \pm 0.27$ & $2.11 \pm 0.38$ & 0.08 \\
Vm & $5.04 \pm 0.18$ & $4.88 \pm 0.25$ & 0.12 \\
Cm & $1.58 \pm 0.16$ & $1.33 \pm 0.19$ & 0.15 \\
\hline
\end{tabular}

Morphometric fidings. The obtained morphometric data are presented in the Tables II-V. Based on statistical analysis, the difference of osteometric parameters between male and female Saanen goat was not significant ( $p>0.05)$. The skull length in Saanen goat was as much as $22.67 \pm 0.93 \mathrm{~cm}$, which $14.3 \pm 0.44 \mathrm{~cm}$ of this length was related to the facial length and $8.37 \pm 0.87 \mathrm{~cm}$ of this was composed by cranial length. The skull height and width were measured as long as $11.47 \pm 0.68$ and $11.81 \pm 0.28 \mathrm{~cm}$, respectively. The height and length of the lower jaw were $9.41 \pm 0.59$ and $17.3 \pm 0.99 \mathrm{~cm}$, respectively, whereas, the length of Bar was recorded to be $4.5 \pm 0.31 \mathrm{~cm}$. The distance between the facial tuberosity and infraorbital canal was $1.57 \pm 0.18 \mathrm{~cm}$ and the distance between the infraorbital canal and alveolar teeth was $3.28 \pm 0.17 \mathrm{~cm}$. The mental foramen was located on the bar region with a $2.45 \pm 0.38 \mathrm{~cm}$ distance from the most lateral incisive tooth and $2.15 \pm 0.09 \mathrm{~cm}$ distance from the first premolar tooth.
The distance between the mental foramen and caudal margin of the mandibular ramus was measured to be $15.35 \pm 0.34$ $\mathrm{cm}$. The mandibular foramen was placed $2.14 \pm 0.11 \mathrm{~cm}$ away from the caudal margin of the mandible and $4.19 \pm 0.1 \mathrm{~cm}$ away from the ventral margin of the mandible, on the medial surface of the ramus. The skull index, facial index and cranial index were estimated to be $52.15 \pm 2.11,65.26 \pm 4.1$ and $101.62 \pm 15.44$, respectively.

Table II. Cranialand facialmorphometric parameters $(\mathrm{cm})$ of Saanen goat $(n=20)$ are expressed as Mea \pm SD.

\begin{tabular}{lccc}
\hline Parameters & Male & Female & P-value \\
\hline SL & $22.17 \pm 3.55$ & $24.21 \pm 1.17$ & 0.19 \\
SH & $11.46 \pm 1.56$ & $10.58 \pm 0.51$ & 0.82 \\
SW & $11.86 \pm 0.25$ & $11.22 \pm 0.33$ & 0.99 \\
CL & $8.18 \pm 1.75$ & $8.55 \pm 0.24$ & 0.75 \\
CW & $8.51 \pm 1.25$ & $7.26 \pm 0.75$ & 0.63 \\
FL & $14.54 \pm 3.12$ & $14.77 \pm 0.88$ & 0.27 \\
FW & $9.52 \pm 0.56$ & $9.12 \pm 0.57$ & 0.65 \\
FI & $1.61 \pm 0.22$ & $1.44 \pm 0.25$ & 0.18 \\
IA & $3.11 \pm 0.23$ & $3.18 \pm 0.14$ & 0.22
\end{tabular}

Skull length (SL), Skull height (SH), Skull width (SW), Cranial length (CL), Cranial width (CW), Facial length (FL), Facial width (FW).Facial tuberosity to infraorbital canal (FI), Infraorbital canal to root of the alveolar tooth (IA).

Table III. Mandibular morphometric parameters $(\mathrm{cm})$ of Saanen goat $(n=20)$ are expressed as Mea \pm SD.

\begin{tabular}{lccc}
\hline Parameters & Male & Female & P-value \\
\hline MH & $9.44 \pm 1.33$ & $9.12 \pm 0.33$ & 0.25 \\
ML & $17.56 \pm 2.81$ & $17.79 \pm 0.25$ & 0.66 \\
BL & $4.52 \pm 0.81$ & $4.63 \pm 0.21$ & 0.13 \\
MFID & $2.51 \pm 0.33$ & $2.55 \pm 0.71$ & 0.51 \\
MFPD & $2.18 \pm 0.08$ & $2.22 \pm 0.17$ & 0.22 \\
MFVD & $0.91 \pm 0.05$ & $0.94 \pm 0.81$ & 0.18 \\
MFC & $15.11 \pm 0.28$ & $15.53 \pm 0.29$ & 0.54 \\
M1 & $4.18 \pm 0.75$ & $3.95 \pm 0.66$ & 0.78 \\
M2 & $2.11 \pm 0.63$ & $2.07 \pm 0.45$ & 0.26 \\
M3 & $4.01 \pm 0.21$ & $4.15 \pm 0.56$ & 0.15 \\
\hline
\end{tabular}

Mandibular height (MH), Mandibular length (ML), Bar length (BL), distance from the mental foramen to the most lateral incisive tooth (MFID), distance from the mental foramen to the cranial margin of the first premolar tooth (MFPD), distance from the mental foramen to the ventral margin of the mandibular body (MFVD), distance from the caudal margin of the mandibular ramus to the mental foramen (MFC), distance from the ventral margin of the mandible to the ventral margine of the mandibular foramen (M1), diastance from thecaudal margin of the ramus to the mandibular foramen (M2), distance between the mandibular foramen and caudal angle of the mandible (M3).

Table IV. Cranial and facial indices of Saanen goat $(n=20)$ are expressed as Mea \pm SD.

\begin{tabular}{lccc}
\hline Indices no & Male & Female & P-value \\
\hline S kull index & $53.45 \pm 1.55$ & $46.34 \pm 1.07$ & 0.49 \\
Facial index & $65.47 \pm 1.22$ & $61.74 \pm 0.35$ & 0.74 \\
Cranial index & $104.94 \pm 6.88$ & $84.81 \pm 3.18$ & 0.02 \\
Nasal index & $36.17 \pm 1.07$ & $35.56 \pm 1.13$ & 0.22 \\
\hline
\end{tabular}


WANG, X.; LIU, A.; ZHAO, J.; ELSHAER, F. M. \& MASSOUD, D. Anatomy of the skull of Saanen goat. An anesthesiology and stereology approach. Int. J. Morphol., 39(2):423-429, 2021.

Table V. Comparison of mandibular morphometric parameters in Saanen goat and other goat breeds. Data are expressed as Mea \pm SD.

\begin{tabular}{lccccc}
\hline & Male Saanen goat & Female Saanen goat & $\begin{array}{c}\text { Gwembe valley } \\
\text { goat(Kataba et } \\
\text { al., 2014 }\end{array}$ & $\begin{array}{c}\text { Markhoz goat } \\
\text { (Goodarzi and } \\
\text { Hosseini, 2013) }\end{array}$ & $\begin{array}{c}\text { Black Bengal } \\
\text { goat (Uddin } \text { et } \\
\text { al., 2009) }\end{array}$ \\
\hline MH & $9.44 \pm 1.33$ & $6.12 \pm 0.33$ & $6.64 \pm 0.44$ & $8.94 \pm 0.43$ & $8.83 \pm 0.57$ \\
ML & $17.56 \pm 2.81$ & $17.79 \pm 0.25$ & $11.24 \pm 0.52$ & $13.37 \pm 0.67$ & $14.21 \pm 0.98$ \\
BL & $4.52 \pm 0.81$ & $4.63 \pm 0.21$ & & & \\
MFID & $2.51 \pm 0.33$ & $2.55 \pm 0.71$ & $1.58 \pm 0.19$ & $1.58 \pm 0.11$ & - \\
MFPD & $2.18 \pm 0.08$ & $2.22 \pm 0.17$ & - & - & - \\
MFVD & $0.91 \pm 0.05$ & $0.94 \pm 0.81$ & - & $11.42 \pm 0.42$ & $11.69 \pm 0.40$ \\
MFC & $15.11 \pm 0.28$ & $15.53 \pm 0.29$ & $9.26 \pm 0.49$ & $3.43 \pm 0.25$ & $3.64 \pm 0.23$ \\
M1 & $4.18 \pm 0.75$ & $3.95 \pm 0.66$ & $2.35 \pm 0.26$ & $1.19 \pm 0.17$ & $1.47 \pm 0.25$ \\
M2 & $2.11 \pm 0.63$ & $2.07 \pm 0.45$ & $1.10 \pm 0.07$ & - & - \\
M3 & $4.01 \pm 0.21$ & $4.15 \pm 0.56$ & - & & - \\
\hline
\end{tabular}

\section{DISCUSSION}

In the present study, the morphometric parameters of the upper and lower jaws were selected using the most relevant superficial and palpable landmarks including infraorbital foramen, mental foramen, facial tuberosity, diastema and mandibular foramen.

Comparing the measured morphometric parameters between the male and female Saneen goats showed no significant differences. This result was in agreement with other previous reports in various goat breeds (GarcíaGonzález \& Barandalla, 2002; Samuel et al., 2013).

The mean total skull length of the Saanen goat was found to be $22.67 \pm 0.93 \mathrm{~cm}$. Previous studies reported 16.99 $\pm 1.59 \mathrm{~cm}$ for West African Dwarf goat (Olopade \& Onwuka, 2005 ) and $18.67 \pm 0.66 \mathrm{~cm}$ for Markhoz goat (Goodarzi \& Hoseini). This shows that the total skull length of the Saanen goat is longer than that those goat species.

The skull index of the Saanen goat was estimated $52.15 \pm 2.11 \%$. This value was more than those stated for Tuj sheep (Özcan et al., 2010) and Markhoz goat (Goodarzi \& Hoseini). This data indicate that the wider skull in the Saanen goat than Markhoz goat and Tuj sheep.

In the present work, the distance between the infraorbital foramen and facial tuberosity as well as the distance between the root of the alveolar tooth and infraorbital foramen was longer than those provided in Markhoz goat (Goodarzi \& Hoseini), West African Dwarf goat (Olopade \& Onwuka, 2005) and Iranian native goat (Monfared et al.). In ruminants, the facial tuberosity is the most palpable prominence which can be used as a superficial landmark to explore the infraorbital nerve. In the Saneen goat, infraorbital foramen was located dorsal to the first or upper premolar. This observation was in line with the black Bengal goat (Uddin et al.). From a clinical view, detecting and blocking this nerve leads to anesthetizing the upper lip, nostril and skin of the face at the level of the infraorbital foramen. Therefore, this data can be applied directly by clinicians who are involved in ruminant medicine (Hall et al., 2000).

The distance from the mental foramen to the lateral alveolar root in the Saanen goat $(2.45 \pm 0.38 \mathrm{~cm})$ was not comparable to those observed in the West African Dwarf goat (Olopade \& Onwuka, 2005), Markhoz goat (Goodarzi \& Hoseini), Maradai goat of Nigeria (Olopade \& Onwuka, 2007), and Iranian native goat (Monfared et al.). This landmark is also clinically important for detecting the site of the mental nerve. Successful blocking of this nerve results in analgesia of the lower incisive and premolar teeth and lower lip (Hall et al.).

In addition to the mental nerve, the mandibular nerve is also of clinical importance. Therefore, its distance from mandibular angle, caudal margin of the mandibular ramus and ventral margin of the mandibular body would be helpful to determine the exact site of the nerve. In this regard, other morphometric parameters such as mandibular length (17.3 \pm 0.99 in male and 17.93 \pm 0.54 in female) and mandibular height $(9.41 \pm 0.59$ in male and $9.23 \pm 0.71$ in female) are effective for localizing the mandibular nerve (Hall et al.).

The differences observed in the morphometric measurements of the head of the Saanen goat and other goat species reported in literature could be due to the adaptations of skull structures to the environmental factors of various geographic locations where the goats arise (Albarella et al., 2009). 
The paranasal sinuses are air-filled spaces lined with a thin layer of respiratory mucosa which make them susceptible to chronic infections and inflammation. In spite of the sensitive structure (Kawarai et al., 1999). Any pathological conditions such as hypoplasia, atelectasia, and sinusitis can be interpreted by knowing the normal volumetric properties of the sinuses. Moreover, the paranasal sinus anatomy should be considered for endoscopic sinus surgeries (Bargbrouth et al., 2002).

In another part of the present work, we applied the sterological methods in combination with CT scan imaging to provide a basic data for volumetric properties of the paranasal and conchal sinuses of Saanen goat in normal condition. The combination of imaging techniques such as CT scan and MRI (Magnetic Resonance Imaging) with Cavalieri principles were used frequently in human medicine for volume estimations in normal and pathological conditions (Kawarai et al.; Emirzeoglu et al., 2005, 2007). In veterinary medicine, squamous cell carcinoma of the paranasal sinuses, alveolitis, sinusitis, sinonasal neoplasia, and cerebral abscess are some of the pathological lesions that were previously subjected to diagnosis in goats using CT scan imaging (Gerros et al., 1998). In a study, DeVilbiss et al. (2013) used of CT imaging to investigate the symptoms of leukoencephalomyelitis due to caprine arthritis encephalitis virus in a 5-year-old Australian Cashmere goat. The only study on dimension of the cranial cavity in goat was done by Rodrigues et al. (2010). These authors did not use CT scan imaging or stereological methods for their evaluation. Bahar et al. (2014) investigated the two and three dimensional anatomy of paranasal sinuses in Arabian foals on CT scan, but did not use Cavalieri principles. Another study was performed to determine the volume of the frontal sinus in giraffe and some artiodactyls species using three dimensional reconstruction without using stereological methods (Badlangana et al., 2011). The present results showed that the frontal sinus was the largest one in male or female Saanen goats. The size of the frontal sinus in ruminants is closely related to the size of the frontal bone, but are less dependent to the overall cranial size or horn size. This indicates a purely structural role for the frontal sinuses in horned ruminants (Farke, 2010). The ventral nasal meatus with volume $5.3 \pm 0.29 \mathrm{~cm} 3$ was the largest meatus in the nasal cavity. This finding indicates that vental meatus in the Saanen goat is the best suitable passage for inserting nasal or endoscopic tubes.

In conclusion, as far as we know, there is a few information about these morphometric and volumetric parameters in the Saanen goat skull. Therefore, these findings provide a basic data that would be useful for blocking terminal branches of the cranial nerves in this breed for surgical purpose or teeth injuries treatment as well as for diagnosis pathological conditions which alter the volume of the paranasal sinuses.

\section{ACKNOWLEDGEMENTS}

The financial supports of the 960th Hospital of the Joint Service of the Chinese People's Liberation Army, Jinan, Shandong, China, and Fayoum University, Fayoum, Egypt, are highly appreciated.

WANG, X.; LIU, A.; ZHAO, J.; ELSHAER, F. M. \& MASSOUD, D. Anatomía del cráneo de la cabra Saanen. Un enfoque desde la anestesiología y la estereología. Int. J. Morphol., 39(2):423-429, 2021.

RESUMEN: La cabra Saanen es conocida como la mayor productora de leche entre las razas de pequeños ruminos, sin embargo, sus características morfométricas aún permanecen sin revelar. Por lo tanto, el presente trabajo tuvo como objetivo investigar la anatomía de los huesos del cráneo y cara, así como sus propiedades volumétricas, en la cabra Saanen, tanto del macho como de la hembra con la finalidad de contribuir con las aplicaciones clínicas. Se incluyeron las cabezas de 20 animales adultos (10 machos y 10 hembras). Se midieron 22 parámetros morfométricos en imágenes de tomografía computarizada tridimensionales utilizando el software RadiAnt DICOM Viewer; algunos parámetros se midieron en muestra macerada en calor. El volumen medio de los senos paranasales y concales se estimó mediante método estereológico. En base a los resultados, las diferencias entre machos y hembras no fueron significativas $(\mathrm{p}>0.05)$ en todos los parámetros deseados. Los senos frontal y lagrimal eran de mayor y menor volumen en ambos sexos, respectivamente. Además, los senos conchal dorsal y medio eran los más grandes y los más pequeños, respectivamente. El meato nasal común fue el más pequeño y el meato ventral el más grande en la cavidad nasal. En conclusión, estos hallazgos brindan un dato básico que sería útil en el bloqueo de las ramas terminales de los nervios craneales en esta raza, con fines quirúrgicos o tratamiento de lesiones dentales.

PALABRAS CLAVE: Anatomía aplicada; Tomografía computarizada; Morfometría; Rumiante; Estereología.

\section{REFERENCES}

Albarella, A.; Dobney, K. \& Rowley-Conwy, P. Size and shape of the Eurasian wild boar (Sus scrofa), with a view to the reconstruction of its Holocene history. Environ. Archaeol., 14(2):103-36, 2009.

Badlangana, N. L.; Adams, J. W. \& Manger, P. R. A comparative assessment of the size of the frontal air sinus in the giraffe (Giraffa camelopardalis). Anat. Rec. (Hoboken), 294(6):931-40, 2011.

Bahar, S.; Bolat, D.; Dayan, M. O. \& Paksoy, Y. Two- and three-dimensio- 
nal anatomy of paranasal sinuses in Arabian foals. J. Vet. Med. Sci., 76(1):37-44, 2014.

Baranowski, P. Morphometric analysis of early medieval dog skulls from Pomerania allowing for forehead position index and dorsal notch of the foramen magnum. E. J. P. A. U., 13(4):16-28, 2010.

Bargbrouth, G.; Prior, J. O.; Lepori, D.; Duvoisin, B.; Schnyder, P. \& Gudinchet, F. Paranasal sinuses in children: size evaluation of maxillary, sphenoid, and frontal sinuses by magnetic resonance imaging and proposal of volume index percentile curves. Eur. Radiol., 12(6):14518, 2002.

DeVilbiss, B.; Neelis, D.; Ochoa, J.; Ziegler, J.; Barrington, G. \& Allen, A. Computed tomography findings in a 5-year-old Australian Cashmere goat (Capra hircus) suffering leukoencephalomyelitis due to caprine arthritis encephalitis virus. Can. Vet. J., 54(10):960-4, 2013.

Emirzeoglu, M.; Sahin, B.; Bilgic, S.; Celebi, M. \& Uzun, A. Volumetric evaluation of the paranasal sinuses in normal subjects using computer tomography images: a stereological study. Auris Nasus Larynx, 34(2):191-5, 2007.

Emirzeoglu, M.; Sahin, B.; Selcuk, M. B. \& Kaplan, S. The effects of section thickness on the estimation of liver volume by the Cavalieri principle using computed tomography images. Eur. J. Radiol., 56(3):391-7, 2005.

Farke, A. A. Evolution and functional morphology of the frontal sinuses in Bovidae (Mammalia: Artiodactyla), and implications for the evolution of cranial pneumaticity. Zool. J. Linn. Soc. Lond., 159(4):988-1014, 2010.

Frazho, J. K.; Tano, C. A. \& Ferrell, E. A. Diagnosis and treatment of dynamic closed-mouth jaw locking in a dog. J. Am. Vet. Med. Assoc., 233(5):748-51, 2008.

García-González, R. \& Barandalla, I. Sexual dimorphism of pyrenean chamois (Rupicapra p. pyrenaica) based on skull morphometry. Pirineos, 157:25-37,2002

Gerros, T. C.; Mattoon, J. S. \& Snyder, S. P. Use of computed tomography in the diagnosis of a cerebral abscess in a goat. Vet. Radiol. Ultrasound, 39(4):322-4, 1998

Gocmen-Mas, N.; Pelin, C.; Canan, S.; Yasici, A. C.; Zagyapan, R.; Senan, S.; Karabekir, H. S. \& Sahin, B. Stereological evaluation of volumetric asymmetry in healthy human cerebellum. Surg. Radiol. Anat., 31(3):177-81, 2009.

Goodarzi, N. \& Hoseini, T. S. Morphologic and osteometric analysis of the skull of Markhoz goat (Iranian angora). Vet. Med. Int., 2014:972682, 2014.

Hall, L. W.; Clarke, K. W. \& Trim, C. M. Wright's Veterinary Anaesthesia and Analgesia. $10^{\text {th }}$ ed. London, ELBS and Bailliere Tindall, 2000.

Jakubowski, H.; Komosa, M. \& Frackowiak, H. Allometric analysis of cranial parameters of American mink, including bones of masticatory apparatus. E. J. P. A. U., 11(3):2-10, 2008.

Kawarai, Y.; Fukushima, K.; Ogawa, T.; Nishizaki, K.; Gunduz, M.; Fujimoto, M. \& Masuda, Y. Volume quantification of healthy paranasal cavity by three-dimensional CT imaging. Acta Otolaryngol. Suppl., 540:45-9, 1999.

Kurtul, I. \& Atalgin, S. H. Scanning electron microscopic study on the structure of the lingual papillae of the Saanen goat. Small Rumin. Res., 80(1-3):52-6, 2008.

Monfared, A L..; Naji, H. \& Sheibani, M. T. Applied anatomy of the head region of the iranian native goats (Capra hircus). Glob. Vet., 10(1):604, 2013.

Morrow, K. L.; Park, R. D.; Spurgeon, T. L.; Stashak, T. S. \& Arceneaux, B. Computed tomographic imaging of the equine head. Vet. Radiol. Ultrasound, 41(6):491-7, 2000.

Olopade, J. O. \& Onwuka, S. K. A craniometric analysis of the skull of the Red Sokoto (Maradi) goat (Capra hircus). Eur. J. Anat., 12(1):57-62, 2008.

Olopade, J. O. \& Onwuka, S. K. Some aspects of the clinical anatomy of the mandibular and maxillofacial regions of the West African dwarf goat in Nigeria. Int. J. Morphol., 23(1): 33-6, 2005.

Olopade, O. \& Onwuka, S. K. Osteometric studies of the skull of red sokoto
(Maradi) goats (Capra hircus): implications for regional anaesthesia of the head. Int. J. Morphol., 25(2):407-10, 2007.

Onar, V. A morphometric study on the skull of the German shepherd dog (Alsatian). Anat. Histol. Embryol., 28(4):253-6, 1999.

Onar, V.; Belli, O. \& Owen, P. R. Morphometric examination of red fox (Vulpes vulpes) from the Van-Yoncatepe Necropolis in Eastern Anatolia. Int. J. Morphol., 23(3):253-60, 2005.

Özcan, S.; Aksoy, G.; Kürtül, I.; Aslan, K. \& Özüdogru, Z. A comparative Morphometric Study on the skull of the Tuj and Morkaraman sheep. J. Kafkas Univ. Vet. Fak. Derg., 16(1):111-4, 2010.

Parés I Casanova, P. M.; Kamal, S. \& Jordana, J. On biometrical aspects of the cephalic anatomy of Xisqueta sheep (Catalunya, Spain). Int. J. Morphol., 28(2):347-51, 2010.

Rodrigues, R. T. S.; Matos, W. C. G.; Walker, F. M.; Costa, F. S.; Wanderley, C. W. S.; Pereira Neto, J. \& Faria, M. D. Dimensions of the cranium and of the cranial cavity and intracranial volume in goats (Capra hircus LINNAEUS, 1758). J. Morphol. Sci., 27(1):6-10, 2010.

Samuel, O. M.; Olopade, J. O.; Korzerzer, M. R. \& Onwuka, S. K. Craniometric evaluation ofsome cranial indices of clinical significance ingoats (Capra hircus) from the Middle-Belt Region of Nigeria - case for population surveillance and ecomigration. Eur. J. Wildl. Res., 2(4):89-97, 2013.

Sarma, K. Morphological and craniometrical studies on the skull of Kagani goat (Capra hircus) of Jammu Region. Int. J. Morphol., 24(3):449-55, 2006.

Uddin, M. M.; Ahmed, S. S. U.; Islam, K. N. \& Islam, M. M. Clinical anatomy of the head region of the black Bengal goat in Bangladesh. Int. J. Morphol., 27(4):1269-73, 2009.

Corresponding author:

Jing Zhao

Department of Anesthesiology

the 960th Hospital of the Joint Service of the Chinese People's

Liberation Army

Jinan, Shandong, 250031

CHINA

Email: zjkfk960@sina.com

Received: 07-09-2020

Accepted:02-10-2020 